\title{
STUDENTS' MATHEMATICS LEARNING ACTIVITIES IN CLASS X.4 SMAN 2 DUMAI ON COOPERATIVE LEARNING TYPE TEAM GAMES TOURNAMENT
}

\section{AKTIVITAS BELAJAR MATEMATIKA SISWA KELAS X.4 SMAN 2 DUMAI PADA PEMBELAJARAN KOOPERATIF TIPE TEAM GAMES TOURNAMENT}

\author{
Arni Iswari \\ SMA Negeri 2 Dumai \\ Email : arnicantiq79@gmail.com \\ Submitted: (23 April 2020); Accepted: (26 Mei 2020); \\ Published: (31 Mei 2020)
}

\begin{abstract}
The student involvement of class X.4 of SMAN 2 Dumai in the learning mathematics is very low. Students rarely want to be involved and actively participate in efforts to develop their knowledge and skills. Learning activities are still centered on the teacher (teacher's centered) because the teacher is still dominant using the lecture method so that the teacher is more active than the student which causes the learning process to become rigid, less support the development of students' attitudes, knowledge, and skills. The low students'mathematics learning activities are also caused by the low level of student understanding of the subject matter concept. Therefore, this study aims to improve students' mathematics learning activities through the implementation of Cooperative Learning type Team Games Tournament (TGT). This study was a classroom action research consisting of two cycles. Data collection is done by filling out the observation sheets conducted by peers during the learning process. Based on the results of data analysis it can be concluded that the students' mathematics learning activities in class X.4 of SMAN 2 Dumai have increased from an average of $76.46 \%$ (good) in the first cycle to $94.14 \%$ (very good) in the second cycle.
\end{abstract}

Keywords: Cooperative Learning type Team Games Tournament (TGT), Mathematics larning activities, Classroom action research

\section{PENDAHULUAN}

Sekolah sebagai lembaga pendidikan formal berfungsi untuk membimbing siswa agar memiliki keterampilan, pengetahuan serta sikap positif. Materi yang diberikan serta aktivitas pembelajaran hendaknya ditata sedemikian rupa dalam bentuk programprogram pembelajaran yang kondusif dengan metode yang sesuai sehingga tujuan pembelajaran dapat tercapai. Pelaksanaan program pendidikan tersebut dimaksudkan untuk membantu siswa mengembangkan kepribadiannya sehingga diharapkan sanggup menghadapi rintangan kehidupan, baik saat ini maupun di masa depan.

Belajar adalah aktivitas yang dilakukan siswa untuk mendapatkan pengetahuan, membentuk sikap, dan menguasai keterampilan tertentu melalui pemikiran dan sanubarinya baik secara sistematis maupun tidak sistematis. Aktivitas pembelajaran yang dimaksud saat ini merupakan aktivitas pembelajaran yang dilakukan oleh siswa. Aktivitas belajar ini dapat kelompokkan ke dalam delapan jenis, yaitu aktivitas visual, aktivitas tulisan, aktivitas lisan, aktivitas mendengar, aktivitas motorik, aktivitas mental, dan aktivitas emosional (Diedrich dalam Hamalik, 2011).

Berdasarkan pengalaman peneliti sebagai guru matematika, siswa jarang mau terlibat dan berpartisipasi aktif dalam mengembangkan keterampilan dan pengetahuan. Keterlibatan siswa dalam proses pembelajaran sangat rendah, meskipun diadakan diskusi kelas biasanya didominasi oleh beberapa orang siswa saja yang berkemampuan akademik tinggi. Kegiatan pembelajaran dilakukan guru dengan menggunakan metode ceramah, sehingga guru 
lebih aktif daripada siswa yang mengakibatkan kegiatan belajar menjadi kaku, kurang mendukung pengembangan pengetahuan, sikap, dan keterampilan siswa terutama dalam hal pemecahan masalah.

Pembelajaran yang inovatif, yang relevan dengan keterlibatan dan peran aktif siswa dalam pembelajaran adalah kegiatan yang menjadikan siswa sebagai pusat dalam setiap tahapannya dan keterkaitannya dengan permasalahan dalam kehidupan sehari-hari. Salah satu dari pembelajaran tersebut adalah pembelajaran yang menekankan agar siswa sendiri yang membangun pengetahuannya, sedangkan guru merancang kegiatan pembelajaran untuk meningkatkan atau mengubah pengetahuan awal siswa yang berkaitan dengan aktivitas hidup sehari-hari, dimana siswa dituntun untuk mengonstruksi pengetahuannya sendiri.

Apabila disikapi lebih lanjut, strategi pembelajaran yang kurang menarik, tidak jarang menyebabkan rendahnya penguasaan siswa terhadap materi yang dipelajarinya. Pemahaman siswa terhadap makna pembelajaran masih rendah di SMAN 2 Dumai khususnya kelas X.4 karena siswa jarang dihadapkan pada peristiwa kongkrit yang terjadi dalam kehidupan sehari-hari.

Karena masih banyaknya siswa yang tidak tuntas berdasarkan hasil ulangan matematika, maka guru perlu mengubah strategi pembelajaran. Untuk meningkatkan aktivitas siswa, guru juga harus melakukan inovasi pembelajaran yang mengarahkan siswa lebih aktif secara kelompok besar maupun dalam kelompok kecil, yaitu dengan menerapkan model Pembelajaran Kooperatif tipe Team Games Turnamen (TGT). Model pembelajaran ini menuntut siswa belajar lebih aktif, mandiri, dan bertanggung jawab.

Pembelajaran Kooperatif tipe TGT merupakan transformasi dari pembelajaran kooperatif Think Pair Square (Depari, 2011). Pembelajaran Kooperatif tipe TGT menekankan siswa kepada kerjasama dalam kelompok, sesama siswa saling memotivasi dan saling membantu, guna mencapai tujuan yang sama yaitu prestasi kelompok yang maksimal (Lie, 2010). Model Pembelajaran Kooperatif tipe TGT menggunakan turnamen pembelajaran, dan menggunakan kuis-kuis dan sistem skor kemajuan individu.

Pada Pembelajaran Kooperatif tipe TGT, siswa ditempatkan ke dalam kelompok yang beranggotakan 4 sampai 6 orang siswa untuk mempelajari materi atau mengerjakan tugas dari guru. Anggota di masing-masing kelompok diusahakan heterogen dalam kemampuan akademik. Hal ini dimaksudkan agar siswa yang dapat menguasai materi dengan cepat bisa membantu anggota kelompoknya untuk memahami materi tersebut. Selanjutnya seluruh siswa diberikan suatu permainan akademik (turnamen) untuk memastikan bahwa semua anggota di setiap kelompok telah memahami materi yang dipelajari. Dalam permainan ini, siswa dibagi ke dalam kelompok turnamen. Masing-masing kelompok turnamen menempati meja-meja turnamen yang telah disediakan. Anggota kelompok turnamen ini terdiri dari perwakilan masing-masing kelompok yang memiliki kemampuan akademik relatif sama. Para siswa sebagai perwakilan kelompok berlomba dengan perwakilan dari kelompok lain pada meja-meja turnamen (Slavin, 2011). Penentuan siswa pada meja turnamen disajikan pada Gambar 1.

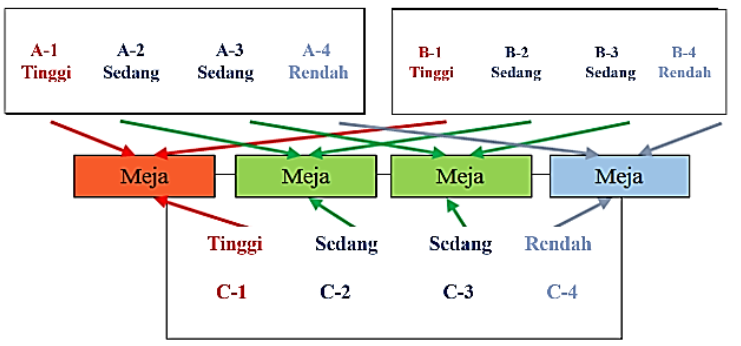

Gambar 1. Penetapan Pemain pada Meja Turnamen

Lie (2010) mengatakan bahwa terdapat lima tahapan pelaksanaan Pembelajaran Kooperatif tipe TGT, yaitu: (1) menyajikan materi, (2) kegiatan kelompok, (3) TGT, (4) perhitungan skor perkembangan individu, dan (5) pemberian penghargaan kelompok. Pembelajaran Kooperatif tipe TGT memiliki ciri-ciri yang khas yaitu pada akhir satu putaran pembelajaran diadakan turnamen yang membuat siswa bersemangat mengikuti pembelajaran sehingga proses pembelajaran 
tidak kaku, mereka bermain dan rileks yang sangat berbeda dengan teacher's centered. Oleh karena itu melalui model Pembelajaran Kooperatif tipe TGT dapat meningkatkan aktivitas siswa dalam pembelajaran. Selain itu melalui pembelajaran kooperatif tipe TGT dapat mengubah paradigma guru dalam melakukan pembelajaran, dari guru sebagai pusat belajar (teacher centered) beralih menjadi siswa sebagai pusat pembelajaran (student centered).

Berdasarkan latar belakang dan fenomena di atas, maka penelitian ini bertujuan untuk meningkatkan aktivitas siswa kelas X.4 SMAN 2 Dumai melalui penerapan model Pembelajaran Kooperatif tipe TGT. Adapun indikator aktivitas siswa yang akan diamati antara lain aktivitas siswa pada saat memperhatikan informasi guru, berada dalam kelompok, mengerjakan LKS, berdiskusi dalam kelompok untuk menyelesaikan LKS, berdiskusi dengan guru, presentasi hasil kerja kelompok, memperhatikan teman yang melakukan presentasi, menuliskan hal-hal yang relevan dengan pelajaran, berada dalam kelompok turnamen, melakukan permainan TGT sesuai dengan peran masing-masing, dan menghitung skor perolehan turnamen.

\section{METODE}

Penelitian ini merupakan Penelitian Tindakan Kelas (PTK) yang dilakukan di kelas melalui kegiatan pembelajaran. Penelitian ini dilaksanakan di kelas X.4 SMAN 2 Dumai Semester Genap Tahun Pelajaran 2017/2018 pada materi Fungsi Komposisi. Pelaksanaan tindakan berupa Pembelajaran Kooperatif tipe TGT dilaksanakan dari bulan Januari 2018 sampai bulan Februari 2018. Subyek penelitian ini adalah siswa kelas X.4 SMAN 2 Dumai yang berjumlah 34 orang yang terdiri dari 13 orang laki-laki dan 21 orang perempuan dengan kemampuan akademik yang heterogen.

Penelitian ini terdiri dari dua siklus. Siklus pertama dilaksanakan dalam lima pertemuan, yaitu tiga kali pembelajaran, satu kali kegiatan turnamen, dan satu kali Ulangan Harian (UH 1). Siklus kedua terdiri dari empat kali pertemuan, yaitu dua kali pembelajaran, satu kali kegiatan turnamen, dan satu kali Ulangan Harian (UH 2).
Setiap siklus dilaksanakan dengan melalui tahap: (1) perencanaan; (2) pelaksanaan; (3) pengamatan, dan (4) refleksi. Dalam PTK siklus selalu berulang (Arikunto, dkk., 2010). Adapun keempat tahapan dalam PTK yang dilakukan peneliti dapat dilihat pada Gambar 2.

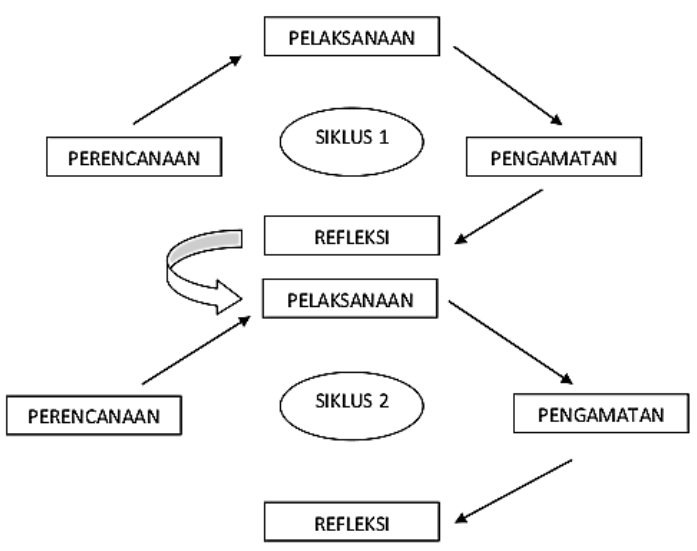

Gambar 2. Siklus Penelitian Tindakan Kelas

Tahap 1. Menyusun perencanaan (planning).

Pada tahap ini, peneliti mempersiapkan perangkat pembelajaran berupa silabus, RPP, dan LKS yang sesuai dengan materi. Perangkat yang dibuat disesuikan dengan langkahlangkah dan karakteristik model Pembelajaran Kooperatif tipe TGT. Untuk kegiatan turnamen, guru menyiapkan satu set kartu TGT yang telah diberi indeks, daftar siswa berdasarkan urutan rangking hasil tes pada semester 1, nomor soal, dan daftar nilai permainan untuk menghitung skor nilai kelompok.

Tahap 2. Pelaksanaan tindakan (acting) Tahap ini merupakan tahap melaksanakan model Pembelajaran Kooperatif tipe TGT dalam pembelajaran. Pada kegiatan pendahuluan guru menginformasikan tujuan pembelajaran yang harus dicapai siswa pada pertemuan tersebut serta memotivasi siswa dengan menyampaikan manfaat mempelajari materi pelajaran dalam kehidupan sehari-hari. Guru menyampaikan cakupan materi dan langkah-langkah kegiatan pembelajaran yang harus dilakukan siswa yaitu aktif berdiskusi dalam kelompok belajar.

Selanjutnya, guru membagi siswa yang berjumlah 34 orang menjadi 8 kelompok 
kooperatif yang masing-masing kelompok terdiri dari 4-5 orang. Kelompok 1 sampai dengan kelompok 6 terdiri dari empat orang, sedangkan kelompok 7 dan kelompok 8 terdiri dari lima orang. Setiap kelompok terdiri dari siswa laki-laki dan perempuan dengan kemampuan tinggi, sedang, dan rendah yang disebut dengan kelompok heterogen (Lie, 2010). Penentuan kelompok ini berdasarkan hasil ulangan matematika siswa pada semester ganjil Tahun Pelajaran 2017/2018.

Dalam kegiatan kelompok, siswa bekerja sama mengerjakan tugas yang diberikan guru. Sumber belajar yang digunakan siswa dalam menyelesaikan tugas di kelompok yaitu LKS dan buku paket matematika kelas X. Setelah masing-masing kelompok menyelesaikan tugas yang diberikan, kemudian masing-masing kelompok mempresentasikan hasil diskusi kelompoknya. Pada kegiatan presentasi, peneliti berperan membantu siswa untuk dapat menyimpulkan materi dari hasil diskusi kelompok.

Untuk mengevaluasi proses dan hasil belajar siswa, peneliti membuat kelompok turnamen, dimana semua siswa yang berkemampuan tinggi dipertemukan pada satu meja turnamen yang sama untuk mendapatkan tambahan skor sebanyak-banyaknya bagi kelompoknya. Begitu juga dengan siswa yang berkemampuan sedang dan rendah. Hal ini untuk mengetahui apakah materi yang disajikan pada proses pembelajaran dapat dikuasai siswa atau tidak.

Turnamen dilakukan dengan cara terlebih dahulu para pemain melakukan undian untuk menentukan pembaca soal dan pemain pertama. Pemain yang memenangkan undian memilih kartu undian yang berisi nomor soal, kemudian memberikannya kepada pembaca soal. Pembaca soal membacakan soal sesuai nomor yang dipilih pemain. Soal tersebut dikerjakan secara individu oleh seluruh pemain pada meja tersebut sesuai batas waktu yang telah ditetapkan. Setelah waktu pengerjaan soal habis, pemain yang telah memilih soal tersebut membacakan jawaban yang diperolehnya, kemudian ditanggapi oleh pemain lain dengan urutan searah jarum jam. Skor yang dikumpulkan peserta dalam turnamen dicatat pada lembar pencatat skor.
Perhitungan skor kelompok dilakukan dengan cara menghitung rata-rata skor yang diperoleh masing-masing anggota kelompoknya. Dari hasil turnamen dihitung berapa jumlah skor tertinggi yang berhasil dikumpulkan masingmasing kelompok. Guru memberikan penghargaan terhadap kelompok yang berhasil mengumpulkan skor tertinggi dan dinyatakan sebagai pemenang.

\section{Tahap 3. Pengamatan (Observing)}

Tahap ini merupakan kegiatan untuk mengumpulkan data yang akurat tentang proses Pembelajaran Kooperatif tipe TGT dan data tentang aktivitas siswa selama pembelajaran. Peneliti dibantu oleh rekan sejawat yang bertindak sebagai pengamat yang hadir di kelas selama pembelajaran berlangsung. Pengamat menuliskan pada lembar pengamatan aktivitas belajar matematika siswa apa yang dilihat dan didengarnya sesuai dengan inidkator yang diamati.

\section{Tahap 4. Refleksi (Reflecting)}

Refleksi merupakan upaya untuk mengkaji apa yang telah tercapai dan yang belum tercapai, baik yang telah berhasil maupun yang belum berhasil dituntaskan dengan perbaikan yang telah dilakukan. Karena PTK dilakukan sebanyak dua siklus, maka hasil refleksi pada siklus pertama menjadi masukan dalam merencanakan tindakan pada siklus kedua. Sedangkan refleksi pada siklus kedua menjadi bahan perenungan dan perencanaan bagi peneliti dalam melaksanakan pembelajaran matematika pada materi selanjutnya.

Data dalam penelitian ini dikumpulkan dengan menggunakan lembar pengamatan aktivitas belajar matematika siswa. Indikator aktivitas siswa yang diamati antara lain aktivitas siswa pada saat memperhatikan informasi guru (aktivitas mendengarkan), berada dalam kelompok, mengerjakan LKS (aktivitas menulis, aktivitas visual, aktivitas mental), berdiskusi dalam kelompok untuk menyelesaikan LKS (aktivitas lisan, aktivitas mental, aktivitas emosional), berdiskusi dengan guru (aktivitas lisan, aktivitas mental, aktivitas emosional), presentasi hasil kerja kelompok (aktivitas lisan, aktivitas mental, 
aktivitas emosional, aktivitas motorik), memperhatikan teman yang melakukan presentasi (aktivitas mendengarkan, aktivitas visual, aktivitas emosional, aktivitas mental), menuliskan hal-hal yang relevan dengan pelajaran (aktivitas menulis, aktivitas mental), berada dalam kelompok turnamen, melakukan permainan TGT sesuai dengan peran masingmasing (aktivitas motorik, aktivitas mental, aktivitas emosional), dan menghitung skor perolehan turnamen (aktivitas mental).

Data yang sudah diperoleh melalui lembar pengamatan kemudian dianalisis. Teknik analisis data yang digunakan adalah analisis statistik deskriptif. Analisis statistik deskriptif bertujuan untuk mendeskripsikan data tentang aktivitas siswa selama proses pembelajaran. Data aktivitas belajar matematika siswa dianalisis secara kuantitatif dalam bentuk persentase. Data jumlah siswa yang terlibat dalam masing-masing aktivitas dan tingkah laku siswa dihitung dengan menggunakan rumus sebagai berikut.

$$
\begin{aligned}
& P=\frac{F}{N} \times 100 \% \\
& \text { Keterangan : } \\
& \mathrm{P}=\text { Persentase } \\
& \mathrm{F}=\text { Frekuensi aktivitas } \\
& \mathrm{N}=\text { Jumlah siswa }
\end{aligned}
$$

Setelah diperoleh persentase aktivitas siswa, kemudian dilakukan interpretasi yang mengacu kepada Arikunto (2009) yang dapat dilihat pada Tabel 1.

Tabel 1. Interpretasi Aktivitas Belajar Siswa

\begin{tabular}{cc}
\hline Interval & Klasifikasi \\
\hline $81 \%-100 \%$ & Baik sekali \\
$61 \%-80 \%$ & Baik \\
$41 \%-60 \%$ & Cukup \\
$21 \%-40 \%$ & Kurang \\
$0 \%-20 \%$ & Kurang sekali \\
\hline
\end{tabular}

\section{HASIL DAN PEMBAHASAN}

Peningkatan aktivitas belajar matematika siswa antara Siklus I dan Siklus II diikuti dengan peningkatan hasil belajar disebabkan oleh beberapa faktor yaitu siswa sudah mengerti dan paham tentang model Pembelajaran Kooperatif tipe TGT. Pembelajaran Kooperatif tipe TGT menuntut kerja keras siswa untuk belajar dan memahami materi pelajaran selain itu kerjasama tim yang solid untuk saling membantu teman satu kelompoknya. Hal ini merupakan modal utama sebelum melaksanakan turnamen karena pada saat turnamen tidak ada kesempatan untuk bekerja sama melainkan menuntut keindividualan siswa dalam mengerjakan soal tanpa meminta bantuan atau berdiskusi dengan kelompok kooperatifnya.

Perkembangan aktivitas belajar matematika siswa selama proses Pembelajaran Kooperatif tipe TGT yang merupakan akibat kegiatan turnamen memberikan pengaruh yang sangat luar biasa. Untuk melihat perkembangan aktivitas belajar matematika siswa dapat dilihat dari perkembangan Siklus I ke siklus II. Data aktivitas siswa selama pembelajaran pada Siklus I disajikan pada

\begin{tabular}{|c|c|c|c|c|c|}
\hline \multirow[b]{2}{*}{ Aktivitas Siswa } & \multicolumn{4}{|c|}{ Pertemuan (\%) } & \multirow{2}{*}{$\begin{array}{c}\text { Rata } \\
- \\
\text { rata } \\
(\%)\end{array}$} \\
\hline & I & II & III & IV & \\
\hline $\begin{array}{l}\text { Memperhatikan } \\
\text { informasi guru }\end{array}$ & 74 & 88 & 91 & - & 84,3 \\
\hline $\begin{array}{l}\text { Berada dalam } \\
\text { kelompok }\end{array}$ & 100 & 100 & 100 & - & 100 \\
\hline $\begin{array}{l}\text { Mengerjakan } \\
\text { LKS }\end{array}$ & 76 & 82 & 88 & - & 82 \\
\hline $\begin{array}{l}\text { Berdiskusi } \\
\text { dalam } \\
\text { kelompok untuk } \\
\text { menyelesaikan } \\
\text { LKS }\end{array}$ & 47 & 53 & 71 & - & 57 \\
\hline $\begin{array}{l}\text { Berdiskusi } \\
\text { dengan guru }\end{array}$ & 29 & 35 & 56 & - & 40 \\
\hline $\begin{array}{l}\text { Presentasi hasil } \\
\text { kerja kelompok }\end{array}$ & 32 & 38 & 47 & - & 39 \\
\hline $\begin{array}{l}\text { Memperhatikan } \\
\text { teman yang } \\
\text { presentasi }\end{array}$ & 62 & 68 & 74 & - & 68 \\
\hline $\begin{array}{l}\text { Menuliskan hal- } \\
\text { hal yang relevan } \\
\text { dengan } \\
\text { pelajaran }\end{array}$ & 65 & 68 & 79 & - & 70,7 \\
\hline $\begin{array}{l}\text { Berada dalam } \\
\text { kelompok } \\
\text { turnamen }\end{array}$ & - & - & - & 100 & 100 \\
\hline $\begin{array}{l}\text { Melakukan } \\
\text { permainan TGT } \\
\text { sesuai dengan } \\
\text { peran masing- } \\
\text { masing } \\
\text { (pengocok, }\end{array}$ & - & - & - & 100 & 100 \\
\hline
\end{tabular}
Tabel 2 berikut.

Tabel 2. Aktivitas Belajar Matematika Siswa selama Pembelajaran Kooperatif Tipe TGT pada Siklus I 


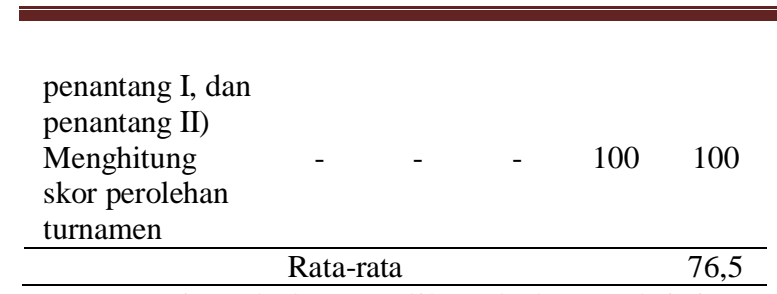

Dari Tabel 2 terlihat bahwa aktivitas siswa memperhatikan informasi guru meningkat dari $74 \%$ (pertemuan I) menjadi $88 \%$ (pertemuan II) dan meningkat lagi pada pertemuan III menjadi $91 \%$ dengan rata-rata persentase aktivitas siswa sebesar 84,3\%. Artinya di setiap pertemuan, semakin banyak siswa yang memperhatikan informasi guru. Hal ini disebabkan pada Pembelajaran Kooperatif tipe TGT guru benar-benar memperhatikan kegiatan siswa sehingga siswa enggan untuk melakukan aktivitas lain di luar pelajaran, siswa merasa seolah-oleh mereka diawasi dengan teliti oleh guru.

Kegiatan siswa berada dalam kelompok pada pertemuan I, II, dan III tidak mengalami penurunan (tetap 100\%) yang berarti bahwa semua siswa selalu berada dalam kelompok selama pembelajaran. Semua siswa duduk dalam kelompoknya masing-masing sesuai dengan kelompok yang telah ditentukan guru dan tidak ada siswa yang tidak mau duduk dalam kelompok karena mereka tidak ingin ketinggalan sendirian di tempat duduknya dan tidak punya teman. Ini merupakan suatu kelebihan pembelajaran kooperatif. Dalam pembelajaran kooperatif tidak ada siswa yang dikucilkan dan tidak ada yang tidak mampu bersosialisasi satu sama lain. Terlebih lagi dalam Pembelajaran Kooperatif tipe TGT, sosialisasi dan kerjasama tim yang baik sangat menentukan keberhasilan timnya dalam turnamen.

Aktivitas siswa mengerjakan LKS dalam kelompok pada pertemuan I yaitu $76 \%$ mengalami peningkatan menjadi $82 \%$ pada pertemuan II dan $88 \%$ pada pertemuan III, dengan rata-rata persentase aktivitas siswa sebesar 82\%. Artinya, jumlah siswa yang terlibat dalam mengerjakan mengerjakan LKS semakin meningkat di setiap pertemuannya. Hal ini terjadi karena pada pembelajaran kooperatif, siswa benar-benar diawasi oleh guru dan memberikan pelayanan yang maksimal. Pada saat kegiatan kelompok, guru berkeliling memantau siswa belajar dari kelompok satu ke kelompok yang lain. Guru juga memberikan penjelasan dan bimbingan kepada kelompok atau siswa yang merasa kesulitan dalam mengajarkan LKS sehingga siswa merasa diperhatikan oleh gurunya. Pada pertemuan I kegiatan siswa mengerjakan LKS hanya $76 \%$, hal ini terjadi karena siswa masih terbawa oleh kebiasaannya yang acuh tak acuh terhadap tugas yang diberikan guru.

Aktivitas siswa berdiskusi dalam kelompok untuk menyelesaikan LKS pada pertemuan I yang sebesar $47 \%$ meningkat menjadi $53 \%$ pada pertemuan II dan $71 \%$ pada pertemuan III, dengan rata-rata sebesar $57 \%$. Hal ini terjadi karena siswa masih terbiasa bekerja sendiri-sendiri dalam kelompok sehingga siswa tidak merasa bertanggung jawab terhadap kelompoknya. Siswa yang tidak mengerti dengan tugas atau materi yang diberikan guru harus berinisiatif sendiri bertanya kepada gurunya. Tetapi walaupun persentase kenaikannya kecil, guru berupaya memberikan pengertian kepada anggota kelompok yang sudah mengerti dengan tugas dan materi yang disampaikan agar mengajari teman satu kelompoknya karena dalam turnamen jika ada salah satu anggota kelompok tidak menguasai materi maka tidak akan bisa memberikan sumbangan yang baik bagi kelompok mereka.

Aktivitas siswa berdiskusi dengan guru jika mengalami kesulitan dalam mengerjakan LKS yang diberikan merupakan hal yang sangat penting dan sangat diharapkan oleh guru. Pada pertemuan I, persentase aktivitas ini meningkat dari $29 \%$ menjadi $35 \%$ pada pertemuan II, dan $56 \%$ pada pertemuan III, dengan rata-rata persentase sebesar $40 \%$. Hal ini disebabkan siswa masih enggan bertanya kepada guru pada pertemuan I, karena biasanya guru sering melemparkan kembali pertanyaan yang diajukan siswa kepada siswa lainnya.

Aktivitas siswa untuk mempresentasikan hasil diskusi kelompok pada pertemuan I, pertemuan II, dan pertemuan III mengalami peningkatan yaitu berturut-turut 32\%, 38\%, dan $47 \%$, dengan rata-rata persentase ebesar $39 \%$. Hal ini terjadi karena pada umumnya siswa merasa enggan/malu maju ke depan kelas untuk mengerjakan soal dan memberikan 
penjelasan kepada teman-teman sekelasnya. Tetapi dengan bimbingan dari guru, pada setiap pertemuannya aktivitas siswa mengalami peningkatan untuk mempresentasikan hasil kerja kelompoknya di depan kelas meskipun angka peningkatannya tidak begitu signifikan. Hal ini sejalan dengan peningkatan aktivitas siswa untuk memperhatikan temannya menjelaskan dan mempresentasikan hasil kerja kelompoknya. Rata-rata persentase aktivitas ini sebesar $68 \%$, dengan rinciannya $62 \%$ pada pertemuan I, $68 \%$ pada pertemuan II, dan $74 \%$ pada pertemuan III.

Aktivitas siswa untuk menulis hal-hal yang relevan dengan pelajaran pada pertemuan I sebesar $65 \%$ meningkat menjadi $68 \%$ pada pertemuan II, dan $79 \%$ pada pertemuan III, dengan rata-rata persentase aktivitasnya sebesar 70,67\%. Hal ini terjadi pada karena pada pertemuan I, siswa malas untuk menulis hal-hal yang relevan dengan pelajaran, namun setelah guru memberikan motivasi dan dorongan serta sedikit pengertian kepada siswa, akhirnya siswa mau mengikutinya.

Aktivitas siswa dalam turnamen pada umumnya sangat baik (100\%). Semua siswa melakukannya dengan penuh semangat dan antusias. Hal ini terjadi karena Pembelajaran Kooperatif tipe TGT ini belum pernah dilakukan oleh guru. Siswa sangat bersemangat karena siswa yang berhasil memperoleh skor tertinggi dalam turnamen dan menjadi kelompok yang terbaik mendapat hadiah yang spesial dari guru. Oleh karena itu siswa berlomba-lomba untuk mengumpulkan skor yang sebanyak-banyaknya dalam turnamen dan ingin menjadi kelompok yang terbaik. Siswa yang berada dalam kelompokkelompok turnamen, melakukan permainan TGT sesuai dengan peran masing-masing (pengocok, penantang I, dan penantang II), menghitung perolehan kartu dan jumlah skor turnamen,

Berdasarkan hasil analisis data dapat dilihat terjadinya kenaikan pada setiap indikator yang diamati oleh observer dalam setiap pertemuan. Tetapi yang paling utama sekali dalam Pembelajaran Kooperatif tipe TGT adalah siswa duduk dalam kelompok, mempresentasikan hasil kerja kelompok, berada dalam kelompok mengikuti permainan, melakukan turnamen sesuai dengan peranannya masing-masing kemudian setelah selesai melakukan turnamen siswa menghitung perolehan kartu dan jumlah skor yang mereka peroleh. Peningkatan dari indikator ini menunjukkan sikap siswa secara khusus dapat meningkatkan hubungan interpersonal yaitu sikap yang fleksibel dan kemampuan dalam merespon perubahan. Dengan adanya hubungan interpersonal pada siswa, maka diharapkan siswa memiliki sikap pengembangan konsep diri, kepercayaan diri, bertanggung jawab, memiliki keterampilan individu serta dapat memberikan kontribusi yang bermakna sehingga melalui proses yang mereka lakukan akan tercapai tujuan pembelajaran.

Berdasarkan pengamatan pada Siklus I, terjadi peningkatan aktivitas siswa baik dari pertemuan I sampai pertemuan IV dengan ratarata peningkatannya $76,5 \%$. Berdasarkan kriteria interpretasi aktivitas belajar menurut Arikunto (2009), nilai tersebut dikategorikan "baik". Jika dilihat secara teliti pada pertemuan III dan pertemuan IV ketika melakukan turnamen, peningkatan aktivitas siswa lebih meningkat dibandingkan dengan pertemuan yang lainnya. Hal ini di sebabkan karena siswa bersemangat dan termotivasi terhadap pelajaran, karena pada pertemuan IV diadakan turnamen yang merupakan ciri khas dari Pembelajaran Kooperatif tipe TGT.

Aktivitas siswa dalam pembelajaran kooperatif tipe TGT pada Siklus II disajikan pada Tabel 3 berikut.

Tabel 3. Aktivitas Belajar Matematika Siswa selama Pembelajaran Kooperatif Tipe TGT pada Siklus II

\begin{tabular}{lcccc}
\hline \multicolumn{1}{c}{ Aktivitas Siswa } & \multicolumn{3}{c}{ Pertemuan (\%) } & \begin{tabular}{c} 
Rata- \\
rata \\
\cline { 2 - 4 }
\end{tabular} \\
\cline { 2 - 4 } & VI & VII & VIII & 100 \\
\hline $\begin{array}{l}\text { Memperhatikan informasi } \\
\text { guru }\end{array}$ & 100 & 100 & - & \\
$\begin{array}{l}\text { Berada dalam kelompok } \\
\text { Mengerjakan LKS }\end{array}$ & 100 & 100 & - & 100 \\
$\begin{array}{l}\text { Berdiskusi dalam } \\
\text { kelompok untuk }\end{array}$ & 94 & 94 & - & 94 \\
$\begin{array}{l}\text { menyelesaikan LKS } \\
\text { Berdiskusi dengan guru }\end{array}$ & 76 & 94 & - & 89,5 \\
$\begin{array}{l}\text { Presentasi hasil kerja } \\
\text { kelompok }\end{array}$ & 79 & 94 & - & 86,5 \\
$\begin{array}{l}\text { Memperhatikan teman } \\
\text { yang sedang presentasi }\end{array}$ & 91 & 100 & - & 95,5 \\
Menuliskan hal-hal yang & 85 & 91 & - & 88
\end{tabular}




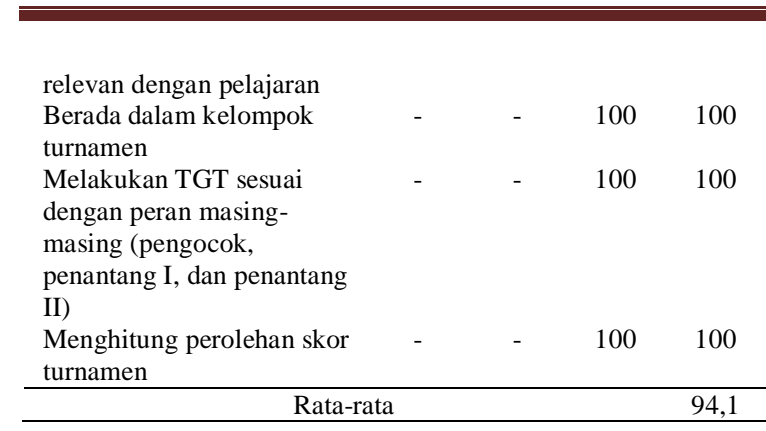

Dari Tabel 3 terlihat bahwa aktivitas siswa memperhatikan informasi dari guru meningkat dari rata-rata $84,34 \%$ pada Siklus I menjadi $100 \%$ pada Siklus II. Hal ini disebabkan pada Pembelajaran Kooperatif tipe TGT, guru benar-benar memperhatikan secara maksimal kegiatan siswa sehingga siswa merasa dibimbing dan merasa dekat dengan guru. Dalam penyampaian informasi pun guru tidak terlalu cepat karena jika guru berbicara terlalu cepat siswa pada umumnya tidak memahami apa yang disampaikan guru.

Aktivitas siswa berada dalam kelompok pada pertemuan VI dan VII tidak mengalami penurunan (tetap 100\%) yang berarti semua siswa senantiasa berada dalam kelompok. Dalam kelompoknya, siswa bersosialisasi satu sama lain dengan latar belakang yang berbeda dan siswa yang kurang mampu mendapat dukungan emosional dan intelektual yang memungkinkan mereka melampaui ambang pengetahuan dan keterampilan mereka sebelumnya. Hal ini berakibat kepada aktivitas siswa berdiskusi dalam kelompok untuk menyelesaikan LKS pada siklus I sebesar 57\% meningkat menjadi $89,5 \%$ pada siklus II. Siswa sudah menyadari bahwa jika mereka tidak menguasai materi, maka mereka tidak akan bisa memberikan sumbangan yang besar bagi kelompoknya.

Aktivitas siswa mengerjakan LKS dalam kelompok pada siklus I dengan rata-rata sebesar $82 \%$ meningkat menjadi $94 \%$ pada siklus II. Hal ini terjadi karena pada pembelajaran kooperatif, siswa benar-benar difasilitasi dan dibimbing oleh guru sehingga siswa dapat memahami materi pelajaran dengan baik.

Aktivitas siswa berdiskusi dengan guru jika mengalami kesulitan dalam mengerjakan LKS merupakan hal yang sangat penting dan sangat diharapkan oleh guru. Pada siklus I, rata-rata persentase aktivitas ini adalah $40 \%$ meningkat menjadi $82 \%$ pada siklus II. Demikian juga halnya dengan aktivitas siswa mempresentasikan hasil diskusi kelompok pada siklus I dengan rata-rata sebesar 39\% meningkat menjadi $86,5 \%$ pada siklus II. Hal ini terjadi karena siswa sudah berani untuk maju ke depan kelas mengerjakan soal dan memberikan penjelasan kepada teman-teman sekelasnya. Aktivitas siswa dalam memperhatikan temannya menjelaskan dan mempresentasikan hasil kerja kelompoknya juga meningkat dari rata-rata $68 \%$ pada siklus I menjadi $95,5 \%$ pada siklus II. Aktivitas siswa untuk menulis hal-hal yang relevan dengan pelajaran dari rata-rata $70,67 \%$ pada siklus I meningkat menjadi $88 \%$ pada siklus II. Pada siklus II, dengan motivasi dan dorongan serta pengertian yang disampaikan guru kepada siswa membuat aktivitas ini meningkat.

Kegiatan siswa pada turnamen siklus I dan II pada umumnya sangat baik (100\%) semua siswa melakukannya dengan penuh semangat dan antusias. Siswa sangat bersemangat untuk mengumpulkan skor tertinggi dalam turnamen dan menjadi kelompok yang terbaik. Oleh karena itu seluruh siswa berlomba-lomba untuk mengumpulkan skor yang sebanyakbanyaknya dalam turnamen.

Berdasarkan uraian di atas, dapat dilihat bahwa terjadi peningkatan aktivitas siswa dari siklus I ke siklus II dalam setiap indikator. Hal ini menunjukkan bahwa Pembelajaran Kooperatif tipe TGT membuat siswa semangat dan termotivasi dalam pembelajaran karena mereka ingin melaksanakan turnamen dengan menyumbangkan skor bagi kelompoknya. Siswa dirangsang untuk memahami materi pelajaran secara bersama-sama di dalam kelompok sebelum melaksanakan turnamen. Siswa diberi kepercayaan penuh oleh kelompok sebagai duta kelompok yang akan bermain pada turnamen dengan harapan membawa hasil yang maksimal sehingga dapat menjadikan kelompoknya sebagai kelompok yang terbaik yang mendapat penghargaan dan hadiah dari guru.

Penerapan model Pembelajaran Kooperatif tipe TGT dapat meningkatkan aktivitas belajar matematika siswa kelas X.4 SMA Negeri 2 Dumai pada materi Fungsi 
Volume 2, Nomor 2, Mei 2020

DOI: https://doi.org/10.33578/prinsip.v2i2.47

jprinsip.ejournal.unri.ac.id

Komposisi. Model pembelajaran ini menjadikan siswa lebih percaya diri dan aktif dalam berdiskusi baik sesama anggota kelompok maupun kepada guru. Peningkatan ini menunjukkan bahwa jika siswa diberikan kesempatan untuk lebih aktif dalam belajar, maka siswa mempunyai kesempatan untuk mengembangkan pengetahuannya sehingga akan tercapai pembelajaran yang efektif yang pada akhirnya hasil belajar siswa menjadi lebih baik.

\section{SIMPULAN}

Berdasarkan hasil penelitian dan pembahasan dapat disimpulkan bahwa penerapan model Pembelajaran Kooperatif tipe TGT dapat meningkatkan aktivitas belajar matematika siswa kelas X.4 SMA Negeri 2 Dumai semester genap tahun pelajaran 2017/2018 pada materi Fungsi Komposisi.

\section{DAFTAR PUSTAKA}

Arikunto, S. (2009). Dasar-dasar evaluasi pendidikan (Edisi revisi). Bumi Aksara
Arikunto, S., Suhardjono, \& Supardi. (2010). Penelitian tindakan kelas (Edisi revisi). Bumi Aksara

Depari, G. (2011). Pembelajaran Kooperatif Team Games Tournament dan Learning Cycle pada Mata Pelajaran Elektronika Digital. Invotec, 7(2), 161 - 174. https://doi.org/10.17509/invotec.v7i2.6 291

Hamalik, O. (2011). Proses belajar mengajar. Bumi Aksara

Lie, A. (2010). Cooperative Learning: Mempraktikkan Cooperative Learning di ruang-ruang Kelas. Grasindo

Slavin, R.E. (2011). Cooperative Learning: Teori, riset, dan praktik. Nusa Media 